International Journal of

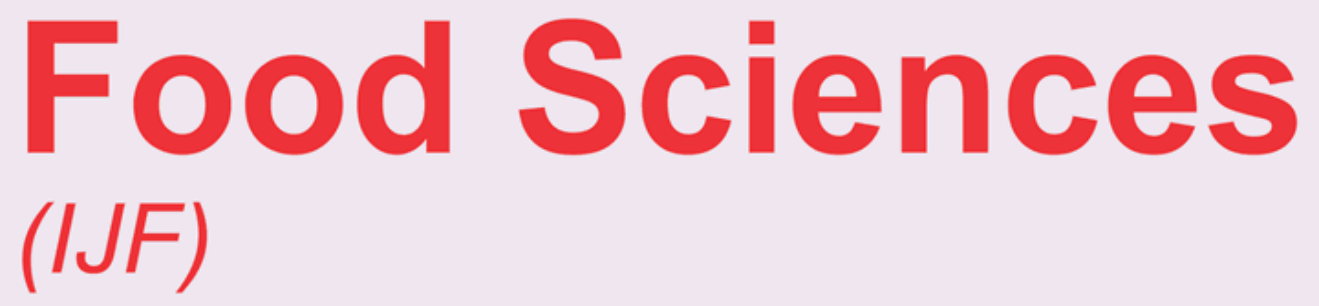

Microbiological and Chemical Evaluation of Traditional Ferment ed Skimmed Milk (nono) in Kano State Nigeria

Sanusi Shamsudeen Nassarawa and Salamatu Ahmad Sulaiman 


\title{
Microbiological and Chemical Evaluation of Traditional Ferment ed Skimmed Milk (nono) in Kano State Nigeria
}

\author{
${ }^{1 *}$ Sanusi Shamsudeen Nassarawa \\ ${ }^{1}$ Lecturer, Department of Food Science and Technology, Faculty of Agriculture, Bayero University \\ Kano \\ *Corresponding Author's Email: shamsudeensunusi2015@gmail.com \\ ${ }^{2}$ Salamatu Ahmad Sulaiman \\ Lecturer, Department of Food Science and Technology, Faculty of Agriculture, Bayero \\ University Kano \\ Corresponding Author's Email: salamatuahmadsulaiman@gmail.com
}

\begin{abstract}
Purpose: Culturally, consumption of local fermented skimmed milk (nono) is common in Northern Nigeria and many other parts of Africa. However, this is, associated with foodborne related diseases resulting from poor hygienic practices.

Methodology: Purposive sampling was used to collect a total of 12 different fermented products from Kano metropolis, Kano State, Nigeria.

Findings: The results obtained showed ranges of different parameters as $\mathrm{Ph}(4.890 \pm 0.01414 \mathrm{t}$ o4.450 \pm 0.07071$)$, titratable acid value $(0.315 \pm 0.06364$ to $0.270 \pm 0.0000)$, moisture content $(92.090 \pm 10.5640$ to $80.730 \pm 3.7760)$ and total solid $(19.270 \pm 3.7760$ to $7.910 \pm 10.5604)$. The total bacterial count ranged from $\left(8.766 \pm 0.3512 \times 10^{3} \mathrm{CFU} / \mathrm{ml}\left(\log _{10} 4.94\right)\right.$ to $1.150 \pm 0.0700 \times$ $10^{3} \mathrm{CFU} / \mathrm{ml}\left(\log _{10} 4.06\right)$, with fungal count of $2.400 \pm 0.2646 \times 10^{3} \mathrm{CFU} / \mathrm{ml}\left(\log _{10} 4.38\right)$ to $0.733 \pm 0.1528 \times 10^{3} \mathrm{CFU} / \mathrm{ml}\left(\log _{10} 3.87\right)$, coliform count of 14 to $<3(\mathrm{MPN} / \mathrm{ml})$ and Staphylococcal count between the ranged of $8.567 \pm 0.7095 \times 10^{3} \mathrm{CFU} / \mathrm{ml}\left(\log _{10} 4.92\right)$ to 2.867 $\pm 0.9504 \times 10^{3} \mathrm{CFU} / \mathrm{ml}$ ( $\log _{10} 3.46$ ). The bacteria isolated were Staphylococcus spp, Bacillus spp, Micrococcus spp, Streptococcus, and E. coli, Moreover, the fungal isolates from the samples included Aspergillus niger, Aspergillus flavus, Mucor and Rhizopus stolonifera. The fermented skimmed milk consumed in the study area was found to be of low quality. Thus, awareness should be strengthened on hygienic methods of production, handling, and selling to the consumers.
\end{abstract}

Unique contribution to theory, practice and policy: This study was conducted to assess the microbial quality and chemical parameters that determined the safety of the products.

Keyword: Fermented milk, nono, microorganism, physicochemical analyses, microbial analyses.

\subsection{INTRODUCTION}

Fermented foods and beverages constitute a major portion of people's diets all over the world and provide $20-40 \%$ of the total food supply. In addition from providing variety to foods, fermented foods have the advantage of prolonged shelf-life due to the organic acids such as lactic acid, acetic acid, and other acids that are produced during fermentation which lowers the $\mathrm{pH}$ thus inhibiting the growth of spoilage microorganisms (Abeer and Dardir, 2009). Milk has been preserved since early times by fermentation. Many traditional fermented milk products were made in Asia, Africa, the Middle East, and northern and eastern Europe. The 
microbiological characteristics of several fermented milk products have been studied in Indonesia (Hosono et al., 1989 and Yodoamijoyo et al., 1983), Zimbabwe (Feresu and Muzondo, 1990), South Africa (Keller and Jordan, 1990; Beukes et al., 2001), Morocco (Hamama, 1992), Tanzania (Isono et al.,1994). The nature of fermented milk products differ from one region to another, and the dominant bacteria in fermented milk are progressive type, lactic acid streptococcus, and lactobacilli, which generally suppress the spoilage organisms effectively thus it depends on the local indigenous microflora, which in turn reflect the climate condition of the area. Dairy cattle products are traditionally stapled food commodities for the nomadic population of Northern Nigeria and many other parts of Africa. These products are an essential part of the national economy and serve as major sources of family income and enormous potential in improving public health. Cow milk is utilized in the production of at least 400 different fermented products all over the world (Abeer and Dardir, 2009).

Nono is a fermented milk product mostly consumed by the Hausa and Fulani tribes in northern Nigeria (Okeke et al., 2014). Locally fermented milk is still a very important part of the daily diet; the nature of this product differs from one region to another depending on the local indigenous microflora, reflecting the climatic conditions of the area. These products have one feature in common: fermentation by lactic acid bacteria is an integral part of their manufacture (De vast and Leroy, 2007; Olaoye and Onilude, 2008). In Nigeria, about $90 \%$ of the dairy cattle belong to the Fulani agro-pastoralists, and their women strictly control the processing and marketing of their milk (Chukwuma, 2009). Most of them are not literate; hence, they do not have any food hygiene training and are not aware of the consequences arising from the consumption of contaminate food. The poor handling of dairy cattle products during processing and marketing exposes it to microbial contamination. The lapses in hygienic practices could result in milk-borne diseases such as tuberculosis, diphtheria, listeriosis, brucellosis, and staphylococcal food poisoning, especially among urban residents who drink fresh or fermented milk sold by the Fulani women (Ijah et al., 2002). Contaminated cow milk products pose serious health concerns as such they can no longer be ignored as they are among the main entry routes of microbial contamination into the human dietary system in Africa (Okeke et al., 2012).

Also, the safety of dairy products concerning foodborne diseases is of great concern around the world. This is especially true in developing countries where the production of milk and various milk products takes place under unsanitary conditions and poor production practices (Mogessie, 1990). Food borne diseases have a significant health impact, and their wellpublicized and wide spread outbreaks have created an awareness of their potential threats to human health. This study, therefore, was aimed at determining the chemical and microbiological quality of traditional fermented skimmed milk in Kano State Nigeria.

\subsection{MATERIAL AND METHOD}

\subsection{Description of the Study Area}

Kano State is the most populous state in Nigeria with a population of over $11 \mathrm{~m}$ people according to the 2006 national population commission census (Census, 2006). The Kano metropolis comprises 8 Local Governments including Dala Fagge, Gwale, Kano Municipal, Nassarawa, Tarauni, Ungogo and Kumbotso. It is the third-largest town in Nigeria after Lagos and Ibadan. 


\subsubsection{Materials and Chemicals}

Twelve samples of locally fermented skimmed milk (nono) used in this research were obtained randomly around Kano metropolis which includes: Gaida quarters, Yankaba, Faraway, and Kuntau, where most of the Hausa/Fulani women hawk the product. The samples were collected randomly at these different points, in each settlement from two different sellers aseptically and coded as (sample 1 to 12) for identification and stored in a cool box with ice block during the fieldwork and the samples were transported for analyses. Other chemicals were of analytical grade

\subsubsection{Determination of Physicochemical Parameters}

\section{Determination of $\mathbf{p H}$}

The $\mathrm{pH}$ was determined with a Tabletop universal $\mathrm{pH}$ meter (TECPEL $\mathrm{pH}$ meter model 705), which was calibrated with a buffer solution (acid buffer solution with the $\mathrm{pH}$ value of 4.76) of accurately known $\mathrm{pH}$.

\subsubsection{Determination of moisture content (MC), Total Solid (TS) and Titratable acidity} (TA)

The determination of MC, TA, and TC was determined by using a standard procedure (AOAC, 1999).

\subsubsection{Microbial Analyses}

\section{Media preparation}

All the media used in this study was prepared and handled according to the manufacturer's instructions.

\section{Isolation of the organism}

\section{Enumeration of aerobic mesophilic bacteria}

The serial dilution method was carried out, as described by the American Public Health Association (APHA, 1992). $11 \mathrm{ml}$ of fermented skimmed milk was mixed with $99 \mathrm{ml}$ of $0.1 \%$ peptone water. This was then shaken thoroughly to make a homogenate solution; this was given the dilution of $10-1.1 \mathrm{ml}$ of this prepared solution was transferred into $9 \mathrm{ml}$ of the diluents ( $0.1 \%$ peptone water), this was given the dilution of $10-2$. This procedure was repeated up to the fifth dilution, which gives the dilution of 10-5. The dilution bottles were agitated and responded settled materials. $1 \mathrm{ml}$ of each dilution was then pipetted in to separate corresponding Petri dishes in duplicates. About $15 \mathrm{ml}$ of nutrient agar (NA) cooled to $150 \mathrm{C}$ was poured into each plate. The sample and the agar medium were mixed by rotating the plate on a flat surface and allowed to solidify. The Petri dishes were then inverted and incubated at $350 \mathrm{C}$ for 24-48 hours. Plates containing between 30-300 colonies were selected and counted. The obtained result was multiplied by the dilution factor. This gives the number of bacterial colony-forming units per $\mathrm{ml}$ of the fermented skimmed milk sample (CFU/ml).

\section{Enumeration of mesophilic aerobic fungi/mold}

For the enumeration of mesophilic fungi/mold, the serial dilution method, as described by the American Public Health Association (APHA, 1992) was employed. 11ml of the fermented skimmed milk sample was mixed with $99 \mathrm{ml}$ of $0.1 \%$ peptone water. The sample was shaken thoroughly to make a homogenate solution; this was given the dilution of $10^{-1} .1 \mathrm{ml}$ of this prepared solution were transferred into $9 \mathrm{ml}$ of the diluents $(0.1 \%$ peptone water), this was given the dilution of $10^{-2}$. This procedure was repeated up to the fifth dilution, which gives the final 
dilution of $10^{-5}$. The dilution bottles were agitated to respond to settled materials. $1 \mathrm{ml}$ of each dilution were pipetted in separate Petri dishes in duplicates. About $15 \mathrm{ml}$ of antibiotic supplemented potato dextrose agar (cooled to $45^{\circ} \mathrm{C}$ ) were poured into each plate. The sample and the agar medium were mixed by rotating the plate on a flat surface and allowed solidify.

The Petri dishes were inverted and incubated at $25^{\circ} \mathrm{C}$ for $3-5$ days (APHA, 1992). Plates that contain less than 50 colonies were selected and counted at 3-5 days incubation period. The count was reported as a fungi/mold colony forming unit per $1 \mathrm{ml}$ of fermented skimmed milk samples $(\mathrm{CFU} / \mathrm{ml})$. Sets of control plates for each sample containing agar and diluents were also be incubated to ascertain the sterility of the media.

The number of bacteria/fungi colony forming unit per gram of the samples was calculated using the following formula:

$\mathrm{N}=\mathrm{n} / \mathrm{vd}$

Where;

$\mathrm{N}=$ the number of bacterial colonies per $\mathrm{ml}$ of sample.

$\mathrm{n}=$ number of colonies counted.

$\mathrm{V}=$ volume of sample (inoculums) used.

$\mathrm{D}=$ dilution factor.

\section{Enumeration of Staphylococcus aureus}

$11 \mathrm{ml}$ of the sample was aseptically weighed and transferred in a clean conical flask containing $99 \mathrm{ml}$ of $0.1 \%$ peptone water and stirred to make a homogenate mixture. Decimal dilution of the milk homogenate (1-10-1 to 1-10-5) was prepared by successive transfer of $1 \mathrm{ml}$ of the milk homogenate to $9 \mathrm{ml}$ sterile $0.1 \%$ peptone water in dilution bottles. $0.25 \mathrm{ml}$ of a dilution of a mixture was pipetted onto the surface of the previously duplicate plate of Baird Parker medium, and a sterile bent glass rod was used to spread the inoculums. The plate was incubated at $37 \mathrm{C}$ for 24 hours. Plates containing 3-300 of black and shining colonies were selected and counted. The following biochemical was carried out for Staphylococcus aureus confirmation: Catalase coagulase, carbohydrate fermentation, Urease, Motility, Iodine, Citrate, methyl red, VogesProskauer test, and gram staining.

\section{Test for coliform bacteria using three tube/MPN Technique}

Aseptically, $11 \mathrm{ml}$ of the milk sample was transferred into a sterile conical flask, and $99 \mathrm{ml}$ of $0.1 \%$ peptone water was added and mixed thoroughly.

Decimal dilution of $1: 10^{-3}$ to $10^{-3}$ was prepared by adding $1 \mathrm{ml}$ of the previous dilution to $9 \mathrm{ml}$ of the sterile diluents. The dilution was shaken 25 times in a one-foot arc for 7 seconds.

Three replicate tubes of MacConkey broth per dilution were prepared with $1 \mathrm{ml}$ of the previously prepared 1:10, 1:100 and 1:1000 dilutions.

The tubes were incubated for 24 and $48 \mathrm{~h} \pm 2$ at $35 \mathrm{C} \pm 0.5 \mathrm{C}$, and it was observed at the end of the 24hours for acid production (color change, purple to yellow) and gas production either in the inverted vial or by effervescence produced when the tubes were gently shaken. Negative Control tubes were incubated for an additional 24 hours. All tubes showing gas within $48 \pm 2$ hours were recorded. The number counted was referred to as MPN tables.

\section{Food MPN table}


MPN Table is mostly published for 3, 5, or even 10 tubes per dilution. The MPN index is at a $95 \%$ confidence limit when three tubes are used.

Table 1. MPN Table

\begin{tabular}{|c|c|c|c|c|c|}
\hline \multicolumn{3}{|c|}{ No. of positive tubes } & \multirow[t]{2}{*}{$\begin{array}{c}\text { MPN/g or } \\
\mathrm{ml}\end{array}$} & \multicolumn{2}{|c|}{$95 \%$ confidence limit } \\
\hline $01: 10$ & 0.111111 & 0.736111 & & Lower & Upper \\
\hline 0 & 0 & 0 & $<3$ & ---- & 9.5 \\
\hline 0 & 0 & 1 & 3 & $<0.5$ & 9.6 \\
\hline 0 & 1 & 0 & 3 & $<0.5$ & 13 \\
\hline 1 & 0 & 0 & 4 & $<0.5$ & 20 \\
\hline 1 & 0 & 1 & 7 & 1 & 21 \\
\hline 1 & 1 & 0 & 7 & 1 & 23 \\
\hline 1 & 1 & 1 & 11 & 3 & 36 \\
\hline 1 & 2 & 0 & 11 & 3 & 36 \\
\hline 2 & 0 & 0 & 9 & 1 & 36 \\
\hline 2 & 0 & 1 & 14 & 3 & 37 \\
\hline 2 & 1 & 0 & 15 & 3 & 44 \\
\hline 2 & 1 & 1 & 20 & 7 & 89 \\
\hline 2 & 2 & 0 & 21 & 4 & 47 \\
\hline 2 & 2 & 1 & 28 & 10 & 150 \\
\hline 3 & 0 & 0 & 23 & 4 & 120 \\
\hline 3 & 0 & 1 & 39 & 7 & 130 \\
\hline 3 & 0 & 2 & 64 & 15 & 380 \\
\hline 3 & 1 & 0 & 43 & 7 & 210 \\
\hline 3 & 1 & 1 & 75 & 14 & 230 \\
\hline 3 & 1 & 2 & 120 & 30 & 380 \\
\hline 3 & 2 & 0 & 93 & 15 & 380 \\
\hline 3 & 2 & 1 & 150 & 30 & 440 \\
\hline 3 & 2 & 2 & 210 & 35 & 470 \\
\hline 3 & 3 & 0 & 240 & 36 & 1300 \\
\hline 3 & 3 & 1 & 460 & 71 & 2400 \\
\hline 3 & 3 & 2 & 1100 & 150 & 4800 \\
\hline 3 & 3 & 3 & $<2400$ & 420 & ----- \\
\hline
\end{tabular}

\subsubsection{Selective plating and identification of isolates}

\section{Identification of the aerobic mesophilic bacteria associated with sample}

The color, size, shape and microscopy, surface elevation, and margin of different colonies developing on the plates were observed. A Representative colony of various morphological types was picked and transferred to a freshly prepared, sterilized and solidified Nutrient Agar (NA) and incubated at $35 \mathrm{C}$ for 24 hours to obtain a pure culture of the organisms (APHA, 1992). The isolated organisms were then subjected to Gram's staining techniques as described by Jideani, (2006). The microscopic slide was clean with cotton wool and spirit; a drop of sterile distilled water was placed at the center. With the aid of a sterile wire loop, a portion of bacteria colony was transferred on the drop of the distilled water and spread. 
Thus; a smear of about $17 \mathrm{~mm}$ was made. The chemicals were then allowed to air-dry and then pass over Bunsen flame three times, avoiding overheating. The smear was then flooded with crystal violet for about 30 seconds and then rinsed with clean water. The smear was covered with Gram's iodine and allowed for 30 seconds. It was then decolorized with acetone alcohol for 20 seconds and then rinse with clean water. It was also covered with Safranin for 20 seconds and then rinse with clean water. The slide was placed on a drying rag and which will be dry in air. The stained smear was observed under the microscope (OMAX 40X-2000X Digital LED Compound Microscope ) using oil immersion. Gram-positive bacteria appeared purple in color while Gram-negative bacteria were reddishly retaining the color of the secondary stain (Safranin).

\section{Identification of fungi/molds associated with the milk sample}

The colonies on each plate were counted and recorded, after which each type of fungal colony was sub-cultured onto a fresh medium (PDA) to obtain pure culture in PDA slants. The technique of James and Natalie, (2001) was adopted for identification of the unknown isolated fungi using cotton blue in lactophenol stain. The identification was achieved by placing a drop of the stain on the clean slide with the aid of a mounting needle, where a small portion of the mycelium from the fungal cultures was removed and placed in a drop of lactophenol. The mycelium was spread very well on the slide with the aid of the needle. A cover-slip was gently applied with little pressure to eliminate air bubbles. The slide was then mounted and observed with $\times 10$ and $\times 40$ objective lenses respectively. The species encountered were identified by the following method described by (Cheesbrough, 2000).

\section{Confirmatory test for Coliform group}

Brilliant Green Lactose Broth (BGLB) was prepared by dispensing $10 \mathrm{~g}$ of the powdered BGLB in $250 \mathrm{ml}$ deionized water; it was allowed to soak for 10 minutes, then, $20 \mathrm{ml}$ were distributed each into fermentation bottles and autoclave at $1210 \mathrm{C}$ for 15 minutes. A small portion from the positive MacConkey tubes that shows gas within $48 \pm 2$ hours was inoculated for sub-culture into BGLB broth using a $3 \mathrm{~mm}$ loop. These tubes were inoculated at $350 \mathrm{C} \pm 0.5$ for $48 \mathrm{~h}$, tubes showing gas were recorded, and the number referred to MPN table for 3-tubes dilution, and the result was reported as a confirmed MPN of coliform bacteria per gram of the sample.

\section{Confirmatory test for Escherichia coli}

Eosin Methylene Blue Agar (EMB) was prepared by dispensing $10 \mathrm{~g}$ of EMB in $250 \mathrm{ml}$ deionized water, allowed to soak for 10 minutes, and autoclaved at $1210 \mathrm{C}$ for minutes. After cooling down to $450 \mathrm{C}$, about $15 \mathrm{ml}$ of the medium were poured into each already sterilized Petri dishes and allow cool down and solidify. A small portion from the positive BGBL tubes that shows gas within $24 \mathrm{~h}$ was streaked with the aid of a $3 \mathrm{~mm}$ loop.

The plates were incubated at $440 \mathrm{C}$ for $48 \mathrm{~h}$. Colonies that are metallic sheen were counted and reported as E.coli per $\mathrm{ml}$ of sample.

Biochemical test such as Gram stain, Catalase, coagulate, Urease, Motility, Iodole, Citrate, methyl red, Voges-Proskauer test, Glucose, lactose, gas, and hydrogen sulfide was carried out to identify the isolate.

\subsubsection{Biochemical test}

Catalase tests, coagulate test, methyl red-Voges Proskauer, citrate test, urease test, motility test, and indole test 
Both the biochemical test was carried out according to the method described by (Oyeleke and Mang 2008).

\subsection{STATISTICAL ANALYSES}

Minitab version 16.0 statistical software was used for the statistical analysis. Student t-test and ANOVA were used to assess differences between quantitative variables. For qualitative variables, Chisquare (for association), Kruskal-Wallis statistic test (for differences) were used. $\mathrm{P}<0.01$ were considered to be a significant negative result.

\subsection{RESULTS AND DISCUSSION}

The physicochemical characteristics of the locally fermented skimmed milk were presented in Table 1. The results showed sample twelve having the highest $\mathrm{pH}$ value $(4.89 \pm 0.014140$ whereas sample five have the lowest $\mathrm{pH}$ value $(4.450 \pm 0.07071)$. Regarding the moisture content, sample four has the highest moisture content $(92.090 \%) \pm 10.564$ whereas sample seven had the lowest moisture content $(80.730 \% \pm 3.776)$. The total solid was found in the range of $19.270 \pm 3.776$ in sample seven to $7.910 \pm 10.564$ in sample four. The titratable acid values ranged between $0.3150 \pm 0.06364$ in samples three, nine and eleven and $0.2700 \pm 0.000$ in samples four, five, seven, eight and twelve. Our result relatively corresponded to Rodrigues et al., (2010), who reported that the $\mathrm{pH}$ of fermented milk products was 4.3 to 5.08. The result shows that the samples have a high moisture content of $92.090 \% \pm 10.564$ and a lower moisture content of $80.730 \% \pm 3.776$, the nearly similar result was obtained by (Ammara and Imran, 2010) who analyzed the moisture content of fermented milk and recorded it as $86.29 \%$.

Table 2: Represent the total mesophilic bacterial, fungal (CFU/ml) and Coliform counts of the 12 samples of fermented skimmed milk (nono) analyzed. The total bacterial count range from $8.766 \pm 0.3512 \times 10^{3}$ in sample twelve to $1.15 \pm 0.0700 \times 10^{3} \mathrm{CFU} / \mathrm{ml}$ in sample nine, with fungal count of $2.4 \pm 0.2646 \times 10^{3} \mathrm{CFU} / \mathrm{ml}$ in sample ten to $0.733 \pm 0.1528 \times 103 \mathrm{CFU} / \mathrm{ml}$ in sample five, and a coliform count of 14 to $<3(\mathrm{MPN} / \mathrm{ml})$ and Staphylococcal count between the ranged of $8.567 \pm 0.7095 \times 103 \mathrm{CFU} / \mathrm{ml}$ in sample eleven to $2.867 \pm 0.9504 \times 103 \mathrm{CFU} / \mathrm{ml}$ in sample.

Table 3: The results of morphological, physiological and biochemical tests of the bacterial isolates was carried out and recorded. The result showed that Staphylococcus species, Bacillus species, Micrococcus species, Streptococcus and E. coli were present in the samples of local fermented skimmed milk analyzed.

Table 4: Indicated the occurrence of the bacterial isolates (Staphylococcus spp, Bacillus spp, Micrococcus spp E. coli, and Streptococcus spp) across the twelve samples analyzed. Result presented in the table revealed that Staphylococcus spp (34\%) were present in all the sample, while Bacillus spp was recovered $14.3 \%$ in five samples, Micrococcusspp (14.3\%) in five samples, Streptococcus (20\%) in seven out of the twelve samples and E. coli was recovered $17.1 \%$ present in six samples.

Table 5: Presented the morphology and microscopy of fungal isolates and showed the presence of Aspergillus niger, Aspergillus flavus, Mucor and Rhizopus stolonifer from the fermented skimmed milk samples

Table 6: Showed the occurrence of the fungal isolates (Aspergillus niger, Aspergillus flavus, Mucor, and Rhizopus stolonifera) across the twelve samples analyzed. Aspergillus niger (24.2\%) were present in eight samples, Aspergillus flavus (6\%) was recovered in six samples, 
Mucor (30.3) in ten samples and Rhizopus stolonifera (27.3\%) in nine out of the twelve samples of the local fermented skimmed milk analyzed.

Result presented in table 3 and 4 revealed that Staphylococcus spp (34\%) were present in all the samples, while Bacillus spp were isolated in five samples, Micrococcus spp $(14.3 \%)$ in five samples, Streptococcus (20\%) in seven out of the twelve samples and E. coli was recovered $17.1 \%$ present in six samples. In general, there are different reasons for these bacterial contaminations. In particular practices undertaken during processing such as type of animal house floor and environment, not washing hands and udder before milking, milking sick animals and those with udder problems, water, and utensils used during processing and milk storage duration under room temperature dispose the milk to microbial contaminations. Therefore, more public health education is needed at different levels along the food production chains (farmers, transporters, processors, and consumers) to safeguard the public from health problems emanating from animals. The presence of Staphylococcus species was quite high and was predominant in the entire samples which demonstrates the need for a proper examination by public health inspectors of the production and the need for proper handling during production. Many studies conducted in different areas implicated S. aureus as the common mastitis-causing organism in lactating cows (Kivaria et al., 2006a; Mdegela et al., 2009). According to Bukuku (2013), consumption of milk contaminated with $S$. aureus can pose a potential health hazard because the main threat is based on the fact that about $10 \%$ of mastitis staphylococci are known to be producers of enterotoxins which are heat-stable toxins. Previous reports have associated $S$. aureus with gastroenteritis through these enterotoxins (Mdegela et al., 2009). Since S. aureus is contagious and common colonizer of teat end and the teat canal, the use of therapy such as dry cow and post-milking teat disinfectants can be of great value in controlling the mastitis disease in lactating cows (Mdegela et al., 2009). Unfortunately, these control measures were not observed to be used by most of the small-scale livestock keepers in the study area. The presence of coliform bacteria i.e. E.coli may be a consequence of the low level of hygiene maintained during processing and handling of the product, this includes the handlers, the quality of water used and the utensils. E. coli as the fecal coliforms were detected in six samples $(16.6 \%)$ out of 12 samples. The results are compared with other studies which showed small percent like $4.1 \%$ reported by Kivaria et al. (2006b) and $6.3 \%$ by Karimuribo et al. (2005) and Kivaria et al. (2006a) and that of $2.1 \%$ in Ghana by Donkor et al. (2007). E. coli is an indicator of bacteria for fecal contamination and was detected not at a low rate in this study. The observation cannot be ignored since there are several strains known to be highly pathogenic with the potential of causing illness to consumers. Therefore, E. coli in milk should be taken seriously in order to prevent public health. Bacillus spp and some Streptococcus spp are lactic acid bacteria that grow well in milk and aid in fermentation. However, depends on the local indigenous microflora, and in turn, reflects the climate condition of the area. Streptococcus spp have been implicated in pharyngitis, tonsillitis, arthritis, bone infection, bacterial pneumonia, and rheumatic fever (Okeke et al., 2014). The fungal isolates from the fermented skimmed milk samples included Aspergillus niger $(24.2 \%)$, Aspergillus flavus (6\%), Mucor (30.3) and Rhizopus stolonifera (27.3\%). The presence of fungi in milk products might be attributed to contamination from air, earthenware, or lack of observant of proper hygiene by the local producers, contaminated cattle feed could also be a source of fungi dissemination. The presence of A.flavus in the cow milk products might probably make its consumption hazardous to human health, some strain of Aspergillus flavus produces aflatoxins, a potent toxin that has been implicated in hepatoxicity and cancer in mammals including man (Okeke, 2014). Therefore, based on these results and for the health 
safety of consumers, more food safety education should be given to producers, handlers, and consumers.

Table 1: Physicochemical characteristic of local fermented skimmed milk

\begin{tabular}{rcccccc}
\hline \multicolumn{1}{c}{ Samples } & $\mathbf{p H}$ & Titratable acidity & \multicolumn{2}{c}{ Moisture content } & \multicolumn{2}{c}{ Total solids } \\
\hline 1 & $4.850 \pm 0.07071$ & $0.2250 \pm 0.06364$ & 84.010 & \pm 0.5515 & 15.990 & \pm 0.5515 \\
2 & $4.580 \pm 0.02828$ & $0.2250 \pm 0.06364$ & 90.780 & \pm 2.517 & 12.020 & \pm 6.4770 \\
3 & $4.840 \pm 0.05657$ & $0.3150 \pm 0.06364$ & 84.900 & \pm 0.4243 & 15.100 & \pm 0.4243 \\
4 & $4.550 \pm 0.2121$ & $0.2700 \pm 0.000$ & 92.090 & \pm 10.564 & 7.910 & \pm 10.5640 \\
5 & $4.450 \pm 0.07071$ & $0.2700 \pm 0.1273$ & 85.940 & \pm 1.499 & 14.060 & \pm 1.4990 \\
6 & $4.650 \pm 0.07071$ & $0.2250 \pm 0.06364$ & 86.020 & \pm 0.8202 & 13.980 & \pm 0.8202 \\
7 & $4.885 \pm 0.02121$ & $0.2700 \pm 0.1273$ & 80.730 & \pm 3.776 & 19.270 & \pm 3.7760 \\
8 & $4.525 \pm 0.03536$ & $0.2700 \pm 0.1273$ & 81.990 & \pm 1.428 & 18.010 & \pm 1.428 \\
9 & $4.490 \pm 0.01414$ & $0.3150 \pm 0.06364$ & 87.900 & \pm 0.4243 & 12.100 & \pm 0.4243 \\
10 & $4.830 \pm 0.04243$ & $0.2250 \pm 0.06364$ & $87.020 \pm 0.2546$ & 12.980 & \pm 0.2546 \\
11 & $4.725 \pm 0.03536$ & $0.3150 \pm 0.06364$ & 87.700 & \pm 1.216 & 12.300 & \pm 1.216 \\
12 & $4.890 \pm 0.01414$ & $0.2700 \pm 0.0000$ & 91.120 & \pm 5.261 & 8.870 & \pm 5.2470 \\
\hline
\end{tabular}

Table 2: Total Mesophylic Bacterial, Fungal counts (CFU/ml), and Coliform of the 12 samples of fermented skimmed milk (nono)

\begin{tabular}{|c|c|c|c|c|}
\hline $\begin{array}{l}\mathbf{S} / \\
\mathbf{N}\end{array}$ & $\begin{array}{l}\text { Total plate count } \\
(\text { CFU/ml) Mean } \pm \text { SD }\end{array}$ & $\begin{array}{l}\text { Total staphylococcus } \\
\text { count }(\text { CFU/ml) Mean }\end{array}$ & $\begin{array}{l}\text { Total fungal count } \\
(\text { CFU/ml) Mean } \pm \text { SD }\end{array}$ & $\begin{array}{l}\text { Colifor } \\
\text { m count }\end{array}$ \\
\hline & & \pm SD & & $\begin{array}{l}\text { MPN/m } \\
\text { l }\end{array}$ \\
\hline 1 & $1.173 \times 103 \pm 0.05508$ & $4.800 \times 103 \pm 0.2646$ & $0.967 \times 103 \pm 0.2082$ & 3 \\
\hline 2 & $1.433 \times 103 \pm 0.05508$ & $5.700 \times 103 \pm 1.058$ & $1.567 \times 103 \pm 0$ & 4 \\
\hline 3 & $6.440 \times 103 \pm 4.715$ & $2.867 \times 103 \pm 0.9504$ & $1.933 \times 103 \pm 0.1528$ & 7 \\
\hline 4 & $6.633 \times 103 \pm 0.6658$ & $4.900 \times 103 \pm 0.8000$ & $1.433 \times 103 \pm 0.1528$ & 3 \\
\hline 5 & $4.023 \times 103 \pm 5.090$ & $6.333 \times 103 \pm 1.007$ & $0.733 \times 103 \pm 0.1528$ & $<3$ \\
\hline 6 & $7.600 \times 103 \pm 0.7937$ & $3.267 \times 103 \pm 0.4509$ & $1.400 \times 103 \pm 0.1000$ & 7 \\
\hline 7 & $1.487 \times 103 \pm 0.1464$ & $7.067 \times 103 \pm 0.8083$ & $2.300 \times 103 \pm 0.3606$ & $<3$ \\
\hline 8 & $8.500 \times 103 \pm 0.9849$ & $3 \pm 0.9713$ & $2.067 \times 103 \pm 0.1528$ & 9 \\
\hline $\begin{array}{l}9 \\
1\end{array}$ & $1.150 \times 103 \pm 0.07000$ & $8.000 \times 103 \pm 1.375$ & $1.433 \times 103 \pm 0.2517$ & 4 \\
\hline $\begin{array}{l}0 \\
1\end{array}$ & $1.187 \times 103 \pm 0.04509$ & $3.233 \times 103 \pm 0.6110$ & $2.400 \times 103 \pm 0.2646$ & 14 \\
\hline 1 & $1.720 \times 103 \pm 0.05000$ & $8.567 \times 103 \pm 0.7095$ & $0.933 \times 103 \pm 0.1528$ & 4 \\
\hline
\end{tabular}


Table 3: Morphological, Physiological and biochemical properties of the bacteria isolates

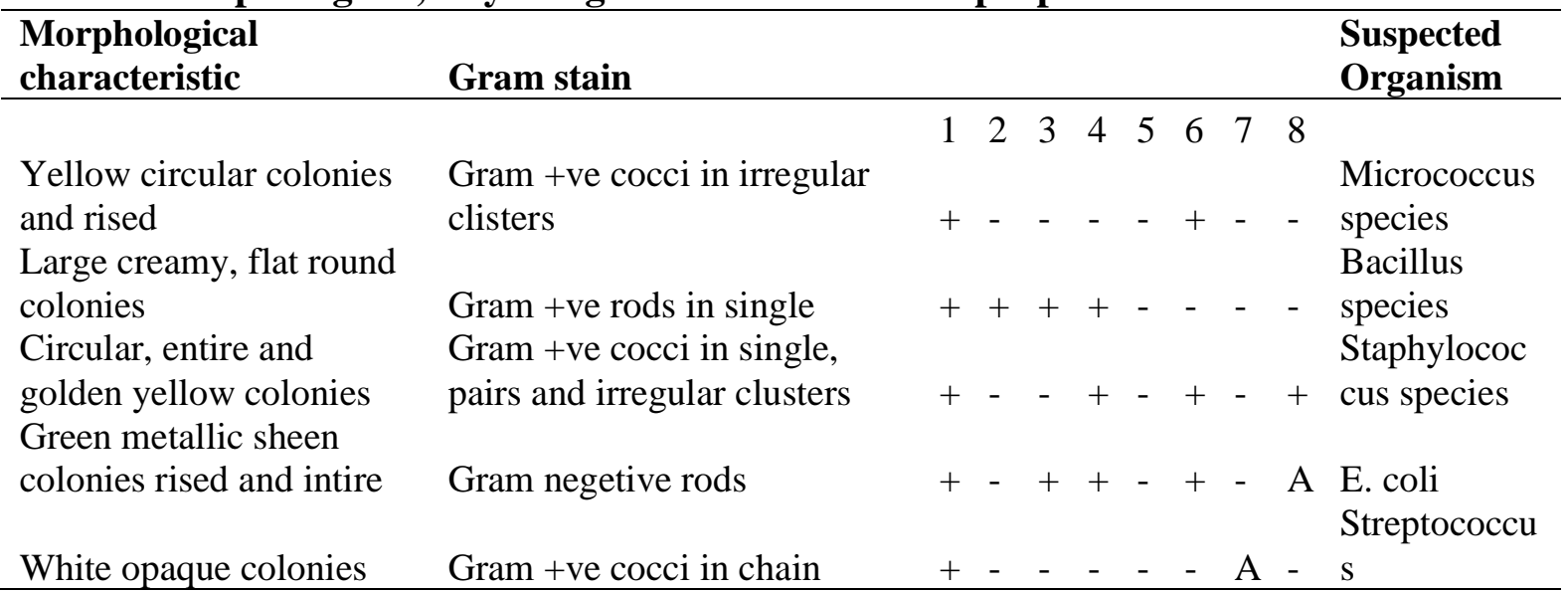

KEY: (1) catalase (2) Motility (3) Simon citrate (4) Methyl red (5) Voges poker (6) Urease activity (7) Indole (8) Coagulase $++=$ Positive $-=$ Negative

Table 4: Occurrence of Bacterial Isolates across the 12 samples analyzed

\begin{tabular}{|c|c|c|c|c|c|}
\hline Samples & $\begin{array}{l}\text { Micrococcus } \\
\text { species }\end{array}$ & $\begin{array}{l}\text { Bacillus } \\
\text { species }\end{array}$ & $\begin{array}{l}\text { Staphylococcus } \\
\text { species }\end{array}$ & $\begin{array}{l}\text { E.c } \\
\text { oli }\end{array}$ & $\begin{array}{l}\text { Streptococcus } \\
\text { species }\end{array}$ \\
\hline 1 & - & + & + & + & - \\
\hline 2 & + & - & + & - & + \\
\hline 3 & + & - & + & + & + \\
\hline 4 & - & - & + & + & + \\
\hline 5 & + & + & + & - & - \\
\hline 6 & - & + & + & - & + \\
\hline 7 & + & - & + & + & + \\
\hline 8 & - & + & + & - & - \\
\hline 9 & - & _ & + & + & + \\
\hline 10 & - & + & + & - & + \\
\hline 11 & + & - & + & + & - \\
\hline 12 & - & - & + & - & - \\
\hline $\begin{array}{l}\text { TOTAL } \\
\%\end{array}$ & 5 & 5 & 12 & 6 & 7 \\
\hline OCCURREN & & & & 17. & \\
\hline CE & 14.3 & 14.3 & 34.3 & 1 & 20 \\
\hline
\end{tabular}

KEY: $\quad+=$ Presence, - =Absence 
Table 5: Morphology and Microscopy of Fungal Isolates

\begin{tabular}{|c|c|c|c|c|}
\hline $\begin{array}{l}\mathbf{S} / \\
\mathbf{N}\end{array}$ & $\begin{array}{l}\text { Sample } \\
\text { s }\end{array}$ & $\begin{array}{l}\text { Morphological } \\
\text { description of } \\
\text { colonies }\end{array}$ & Microscopy & $\begin{array}{l}\text { Suspected } \\
\text { Organism }\end{array}$ \\
\hline 1 & $\begin{array}{l}1,3,4,5, \\
6,7,9, \\
10,11 \text { an }\end{array}$ & $\begin{array}{l}\text { White cottony at } \\
\text { first then grey as } \\
\text { it grows older } \\
\text { d } 12 \text {. }\end{array}$ & $\begin{array}{l}\text { Sporangiophores arise singly from } \\
\text { mycelium at any point. All branches } \\
\text { terminate in sporangia }\end{array}$ & Mucor \\
\hline 2 & $\begin{array}{l}3,4,5,6 \\
7,9 \\
10,11 \text { an }\end{array}$ & $\begin{array}{l}\text { Black dusty and } \\
\text { spongy } \\
12\end{array}$ & $\begin{array}{l}\text { Sporangiophores arises from long arching } \\
\text { stolons opposite rhizoids }\end{array}$ & $\begin{array}{l}\text { Rhizopus } \\
\text { stolonifer }\end{array}$ \\
\hline 3 & $\begin{array}{l}1,2,5,7 \\
8 \text { and } \\
\qquad 11\end{array}$ & $\begin{array}{l}\text { Yellow-green } \\
\text { surface with } \\
\text { reddish-brown } \\
\text { underneath }\end{array}$ & $\begin{array}{l}\text { The apex of the conidiophores is swollen } \\
\text { into a vesicle from which arises bottle- } \\
\text { shaped cells, sterigmata which bear } \\
\text { chains of globose conidiophores }\end{array}$ & $\begin{array}{l}\text { Aspergillus } \\
\text { flavus }\end{array}$ \\
\hline 4 & $\begin{array}{l}1,2,3,4 \\
7,8,9 \\
\text { and } 10\end{array}$ & $\begin{array}{l}\text { Dark-brown to } \\
\text { black } \\
\text { pigmentation }\end{array}$ & $\begin{array}{l}\text { Numerous mycelia conidiophores are } \\
\text { black, spherical to oval, produced in a } \\
\text { long chain }\end{array}$ & $\begin{array}{l}\text { Aspergillus } \\
\text { niger }\end{array}$ \\
\hline
\end{tabular}

Table 6: Occurrence of Fungal Isolates

\begin{tabular}{|c|c|c|c|c|c|c|c|}
\hline $\mathbf{S} / \mathbf{N}$ & $\begin{array}{l}\text { SAMPL } \\
\text { E }\end{array}$ & $\begin{array}{l}\text { Aspergillus } \\
\text { niger }\end{array}$ & $\begin{array}{l}\text { Rhizopus } \\
\text { stolonifer }\end{array}$ & & $\begin{array}{l}\text { Muco } \\
\mathbf{r}\end{array}$ & $\begin{array}{l}\text { Aspergillus } \\
\text { flavus }\end{array}$ & \\
\hline 1 & 1 & + & - & & + & + & \\
\hline 2 & 2 & + & - & & - & + & \\
\hline 3 & 3 & + & + & & + & - & \\
\hline 4 & 4 & + & + & & + & - & \\
\hline 5 & 5 & - & + & & + & + & \\
\hline 6 & 6 & - & + & & + & - & \\
\hline 7 & 7 & + & + & & + & + & \\
\hline 8 & 8 & + & - & & - & + & \\
\hline 9 & 9 & + & + & & + & - & \\
\hline 10 & 10 & + & + & & + & - & \\
\hline 11 & 11 & - & + & & + & + & \\
\hline 12 & 12 & - & + & & + & - & \\
\hline \multicolumn{8}{|l|}{ TOTA } \\
\hline \multicolumn{2}{|c|}{$\mathrm{L}$} & \multicolumn{2}{|c|}{8} & 9 & 10 & & 6 \\
\hline \multicolumn{2}{|c|}{ \%OCCURENCE } & \multicolumn{2}{|c|}{24.2} & 27.3 & 30.3 & & 18.2 \\
\hline
\end{tabular}

Key : $+=$ presence, $\quad-=$ absence

\subsection{CONCLUSION}

In this study, the physicochemical parameters and microbiological quality of fermented milk products (nono) were studies. The physicochemical parameters varied among the different samples analyzed. The microbiological analysis revealed the presence of some pathogenic bacteria including Staphylococcus spp, E. coli, and Aspergillus spp. The growth of these 
pathogenic organisms and their toxins in local dairy cattle products is a reflection of poor sanitary practices in the production of fresh milk and its products. It is however noted that the types of organisms and their density in the milk products from studied sites should be of great concern to the health authorities as these pose serious public health problems to consumers.

The safety of food consumers is of utmost importance; all hands must be on deck to have this assured all the time. Minimizing contamination of the raw materials is, therefore, another way of controlling pathogen levels in the final product. Measures should be taken to prevent the transmission of pathogens to fermented foods at both the household and commercial levels. At the commercial level, improvement of product quality and safety could be achieved by applying Good Manufacturing Practices (GMP), Good Hygienic Practices (GHP) and the Hazard Analysis and Critical Control Point (HACCP) system, for some traditional fermented foods. However, educating food handlers regarding, food hygiene is a strategy that can be used in efforts to prevent food-borne diseases.

\section{Acknowledgment}

The authors wish to acknowledge the assistance of Mal. Sani Abashe for sample analyses

\section{Conflict of interest}

The authors have no conflict of interest to report.

\section{REFERENCE}

Abeer, A.A. and Dardir H.A (2009). Hygienic Quality of Local Fermented Skimmed Milk Sold in Egypt. World Journal of Dairy and Food Sciences. 4 (2): 205-209.

American Public Health Association, (1992). Standard Methods for the Examination of Dairy Products. 16th edition. Washington, DC.

Ammara, K. and Imran, P. (2010). Determination of moisture content in stored yogurt with different starter cultures. Pak Journal of Nutrition. 20(2): 221-227.

AOAC (1990). Association of official analytical chemists. Ash and animal feed (942:05). Official method of analysis, $15^{\text {th }}$ edition

Bertu, W.J., Dapar, M., Gusi, A.M., Ngulukun, S.S., Leo, S. and Jwander, L.D. (2010). Prevalence of Brucella antibodies in marketed milk in Jos and environs. African Journal of Food Science. 4(2): 062 - 064.

Beukes, E.M., Bester, B.H. and Mostert, J.F. (2001). The Microbiology of South African Traditional Fermented Milk. Int. Journal of Food Microbiology. 63(2): 189-197.

Bukuku, J.N. (2013). Awareness of health risks as a result of the consumption of raw milk in Arusha City and Meru District, Tanzania. Unpublished dissertation for award of MSc. degree at Sokoine University of Agriculture, Morogoro, Tanzania. Pp. 1 - 89

Cheesbrough, M. (2000). District Laboratory Practice in Tropical Countries Part 2, Cambridge. University Press, Cambridge. Pp. 47-54.

Chukwuma, M. (2009). Furors over Animal Milk Products rage. World Journal of Microbiology and Biotech. 5(6): 23-30.

De Vuyst, L. and Leroy, F. (2007). Bacteriocins from Lactic acid bacteria: production, purification, and food application. Journal of Microbiol. Biotechnol. 13(3): 194-199. 
Feresu, S.B. and Muzondo, M.I. (1990). Identification of some lactic acid bacteria from two Zimbabwean fermented milk products. Word Journal of Microbiology and Biotech. 6(2): 178-186.

Hoolst, D.O. (1982), Association of Official Analytical Chemists. Pp. 265-269.

Ijah, J.J. Odagboyi, G. and Uwabujo, A.E. (2002). Microbiological Screening of Fura da Nono. Nigeria Journal of Science Tech and Math Edu. 5(1):9-16.

Karimuribo, E.D., Kusiluka, L.J., Mdegela, R.H., Kapaga, A.M., Sindato, C. and Kambarage, D.M. (2005). Studies on mastitis, milk quality and health risks associated with consumption of milk from pastoral herds in Dodoma and Morogoro regions, Tanzania. Journal of Veterinary Science. 6(3): 213 - 221.

Keller, J.J. and Jordan, I. (1990). Fermented Milk for the South African Market. S. Afr. Journal of Dairy Sci. 22(2): 47-49.

Kivaria, F.M., Noordhuizen, J.P.T.M. and Kapaga, A.M. (2006a). Evaluation of the hygienic quality and associated public health hazards of raw milk marketed by smallholder dairy producers in the Dar es Salaam region, Tanzania. Tropical Animal Health Production. 38: $185-94$.

Kivaria, F.M., Noordhuizen, J.P.T.M. and Kapaga, A.M. (2006b). Prevalence and antimicrobial susceptibility of bacteria isolated from milk samples of smallholder dairy cows in Tanzania. In: Epidemiological studies on Bovine mastitis in smallholder dairy herds in the Dar es Salaam region, Tanzania. Thesis for the award of degree of Doctor of Philosophy (Ph.D.) at Utrecht University, Netherlands. Pp. 25 - 36.

Lei, I., Roffey, P., Blanchard, C. and Gu., K. (2008). Development of a multiplex procedure method for the detection of six common foodborne pathogens. Journal of Food and Drug Analysis. 16(4): 37 - 43.

Mdegela, R.H., Ryoba, R., Karimuribo, E.D., Pire, E.J., Løken, T., Reksen, O., Mtengeti E. and Urio, N.A. (2009). Prevalence of clinical and subclinical mastitis and quality of milk in smallholder dairy farms in Tanzania. Journal of the South African Veterinary Association. 80(3):

Mdegela, R.H., Ryoba, R., Karimuribo, E.D., Pire, E.J., Løken, T., Reksen, O., Mtengeti E. and Urio, N.A. (2009). Prevalence of clinical and subclinical mastitis and quality of milk in smallholder dairy farms in Tanzania. Journal of the South African Veterinary Association. 80(3): 163 - 168.

Okeke, K.S. Abdullahi, I.O. and Makun, H.A. (2014). Microbial Quality of Dairy Cattle Products. British Microbiology Research Journal. 4 (12): 1409-1417.

Oyeleke, Solomon Bankole and Manga, BalaShuaibu. (2008). Essential of Laboratory Practicals in Microbiology. Pp. 51-63.

Parekh, T.S. and Subhash, R. (2008). Molecular And Bacteriological Examination Of Milk From Different Milch Animals With Special Reference To Coliforms. Current Research in Bacteriology. 1(2): 56 - 63.

Rodrigues, L.A., Ortalani, M.B.T., Nero, L.A. (2010). Microbial quality of yogurt commercialized in Vicosa, Minas Gerais Brazil. Afri. Journal of Microbiology. Res. 4(3): 210-213. 
Shirima, G.M., Fitzpatrick, J. Cleaveland, S., Kambarage, D.M., Kazwala, R.R., Kunda, J. and French, N.P. (2003). Participatory survey on zoonotic diseases affecting livestock keeping Susan.

Tamime, A.Y. and Robinson, R.K. (1988). Fermented milk and their future trends: Technological aspects. Journal of Dairy Res. 55(3): 281-307

Yodoamijoyo, R.M., Z. Tirza, S.R. Herastuti, A. Tomomatsu, A. Matsuyama and A. Hosono, (1983). Microbiological aspects of Dadih in Indonesia. Journal of Dairy Food Sci. 32(2): 7-14. 